\title{
Australia boosts research
}

Sydney

As announced last week to the Federal Parliament, the Australian government will boost spending on science and technology by 4.3 per cent in real terms, to A $\$ 2,600$ million ( $\$ 2,050$ million).

The budget, which now requires only routine approvals to pass through Parliament, includes a major boost for university research grants, while at the same time cutting funds for the Defence Science and Technology Organisation.

Funds for the centralized university research grants scheme, allocated by the Australian Research Council under a newly unified system, will be increased by 37 per cent, to $\mathrm{A} \$ 271$ million ( $\$ 212$ million). The extra money for the council should please researchers, who complained early this year that the council's inadequate funds made it too difficult to get grants for worthwhile projects.

The increase comes partly at the expense of university research and development funds allocated outside the grants system, which were cut by 6 per cent to A $\$ 840$ million ( $\$ 655$ million). Still, the funds available for university research and development in 1992, counting both the central grants system and other funds, will be 6 per cent more than this year.

Australia's major research organization, the Commonwealth Scientific and Industrial Research Organisation (CSIRO), also did well, considering that the government has been deliberately squeezing the body's funds for several years. CSIRO's funding was increased by 3 per cent to A $\$ 448$ million $(\$ 350$ million), with the organization expected to get another $\mathrm{A} \$ 147$ million from outside

sources such as licence fees and business support for projects.

The defense research organization was the major loser in the budget, as its funds will be cut by 6 per cent, to $A \$ 221$ million ( $\$ 173$ million). No reason was given for the cut, and notes on the organization's research projects included in the budget papers did not say which programmes would be affected by the reduction.

The overall increase of 4.3 per cent in funding follows a 2.6 per cent rise last year and is in line with the government's emphasis on boosting research and development as a means of creating an advanced industrial base. Because Australia relies mainly on mining and farming for exports and has few of the very large high-tech companies found in other advanced countries, the government provides more than half the total funds spent on research and development.

Despite the increasing government emphasis on research, however, figures released with the budget show that private sector spending on research and development has increased very little. As a result, research and development incentives, including revenue lost through a tax concession, are expected to fall by 3 per cent to A\$362 million ( $\$ 282$ million).

As another way to boost industry, the government this year began a cooperative research centres scheme, which is designed to create centres of expertise capable of passing on innovations to local industry. The first 15 centres were announced in March. More centres - eventually there will be 50 - are now being selected and will be revealed later this year.

Mark Lawson

AFRICA

\section{University of Zimbabwe tumult}

\section{Cape Town}

IN protest at increasing government encroachment on academic freedoms at the University of Zimbabwe, vice-chancellor Walter Kamba announced his resignation at the university's mid-year graduation ceremony last month. Kamba's action was made more dramatic by the fact that the occasion was presided over by the progenitor of his discontent, Zimbabwean President Robert Mugabe, who was conferring degrees in his capacity as the university's chancellor.

The resignation, which has been followed by those of at least two other faculty members, is the culmination of a tumultuous semester at the university, in which students boycotted classes for three weeks in response to the Zimbabwe parliament passing the 1990 University
Amendment Act. This gives the government added representation on the university's council, and delegates authority to the vice-chancellor to hire and dismiss faculty and to expel students without any process of appeal - measures that Kamba was loath to implement.

Not everyone will be sorry to see the back of Kamba, whose record of administration during his ten-year tenure has by all accounts not been exemplary. But many academics are even more apprehensive about who will replace him when he leaves office at the end of next month. There are fears that the government will appoint a hardliner from outside the academic sector to 'sort out' activists among the 10,000 -strong student body who are proving to be a thorn in the side of the ruling party.

Michael Cherry

\section{Fullerenes warm up}

Tokyo

ThE temperature at which doped fullerenes can become superconducting seems to be on a dramatic rise. Last week, a group of Japanese researchers claimed they have produced an iodine-doped fullerene that superconducts at $57 \mathrm{~K}-15 \mathrm{~K}$ warmer than the previous record set only a few weeks ago by a team at Allied Signal's laboratories in the United States (Nature 352, 463; 8 August 1991). Allied Signal's record surpassed one of $33 \mathrm{~K}$ set by researchers at Japan's NEC company in July (Nature 352, 222; 18 July 1991).

The Japanese group, led by Hisashi Sekine of the National Research Institute for Metals in Tsukuba science city, says two papers on their research on halogendoped fullerenes have been accepted for publication in the 1 October and 15 October issues of the Japanese Journal of Applied Physics.

David Swinbanks

BRAZIL

\section{Science minister}

\section{takes on a pineapple}

São Paulo

Physicist José Goldemberg has been transferred from his position as Secretary of Science and Technology to take over Brazil's troubled education ministry. Edson Machado, Goldemberg's number two man at the science and technology department, has been given the top job there, but the possibility remains that president Fernando Collor de Mello may decide to merge the two units, creating a 'super ministry' of science, technology and education.

As education minister, Goldemberg's most immediate concern is the state of the federal universities, which consist of about 30 units around the country. The staffs of those universities have been on strike demanding better wages for more than two months.

Goldemberg has criticized the federal institutions, where - with the exception of a few departments - tenure is easy to obtain and little research is done. He has said he will try to create some concrete way to evaluate work at the universities.

In the past 20 years, Brazil has had 11 ministers of education, all but two of whom were politicians or military officers with little or no experience with teaching or education. Goldemberg told an audience of scientists a few weeks ago that whenever Collor tried to speak with him about the Ministry of Education, he would attempt to change the subject. He said he considered the job to be an "abacaxi" Brazilian slang for an unwanted and bothersome problem, literally a "pineapple". Now Goldemberg's friends fear that this is one fruit that may prove rather hard to digest.

Ricardo Bonalume 